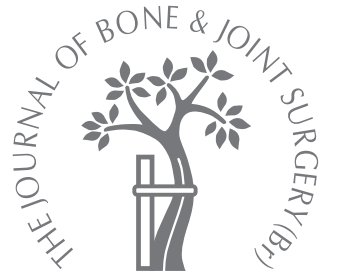

A. Atrey,

I. Leslie,

J. Carvell,

C. Gupte,

J. A. N. Shepperd,

J. Powell,

P. A. Gibb

From The British

Orthopaedic

Association

= A. Atrey, MRCS (Eng), Orthopaedic Specialist Registrar Kent \& Sussex Hospital,

63 Mount Sion, Tunbridge Wells, Kent TN1 1TN, UK.

II I. Leslie, MCh Orth, FRCS (Ed), FRCS (Orth) Past President of the BOA, Consultant Orthopaedic Surgeon

Department of Orthopaedics Bristol Royal Infirmary, Bristol BS2 8HW, UK.

I. J. Carvell, FRCS (Eng), FRCS (Ed). FBOA Chairman of the MedicoLegal Committee of the BOA and CCSC of BMA

Department of Orthopaedics

Salisbury District Hospital,

Salisbury, Wiltshire SP2 8BJ, UK.

C. Gupte, FRCS (Orth), MA

$\mathrm{PhD}$, Specialist Registrar in

Orthopaedics

Department of Orthopaedics

St Mary's Hospital, Praed Street,

Paddington, London W2 1NY, UK.

- J. A. N. Shepperd, FRCS

(Orth), Consultant Orthopaedic

Surgeon

Conquest Hospital, The Ridge, St Leonards-on-Sea, East Sussex TN37 7RD, UK.

II. Jowell, FRCS (Orth), MB BS, Consultant Orthopaedic Surgeon Spinal Unit, Ipswich Hospital, Heath Road, Ipswich IP4 5PD, UK.

= P. A. Gibb, FRCS (Orth)

Consultant Orthopaedic Surgeon

Department of Trauma and

Orthopaedics

Kent and Sussex Hospital,

Tunbridge Wells, Kent TN4 8AT,

UK.

Correspondence should be sent

to $\mathrm{Mr} \mathrm{A}$. Atrey; e-mail:

amitatrey@doctors.net.uk

(2008 British Editorial Society of Bone and Joint Surgery doi:10.1302/0301-620X.90B4 $20497 \$ 2.00$

$J$ Bone Joint Surg $[\mathrm{Br}]$ 2008;90-B:422-3.

\title{
Standardised consent forms on the website of the British Orthopaedic Association
}

\begin{abstract}
The British Orthopaedic Association has endorsed a website, www.orthoconsent.com, allowing surgeons free access to a bank of pre-written consent forms. These are designed to improve the level of information received by the patient and lessen the risk of successful litigation against surgeons and Health Trusts.
\end{abstract}

Litigation against surgeons and hospitals continues to increase in Western countries. ${ }^{1}$ While verbal consent is all that is required legally, it has for a long time been considered that written consent offers proof of discussion and interaction between the surgeon and the patient. Inadequate consenting of patients continues in the United Kingdom despite the best intentions of the Department of Health and standardisation of the appropriate forms. ${ }^{2-4}$ Errors in information and of omission still lead to confused patients, leaving surgeons and Health Trusts open to litigation. A process of consent used nationally and detailing the same complications for each operation may help to facilitate the legal process in that a judge will be aware of the complications stated in a nationally-accepted universal consent form.

By way of standardising the process of consent, the British Orthopaedic Association (BOA) has endorsed a website, www.orthoconsent.com, which contains pre-written consent forms for a growing number of orthopaedic procedures. It is an easily navigable forum which is available without charge to all surgeons. The authors hope that these standardised forms will become the benchmark by which consent is judged.

The site and the intellectual property are owned by the authors, but the entitlement to use them remains free. The organisation of the project has been financed by a sponsor (Finsbury Orthopaedics, Leatherhead, Surrey).

Any surgeon or patient may download the forms from the internet by visiting the site directly. If the surgeon or hospital wishes, a copy of the programme is available to download and add to an already existing intranet service in a hospital. This programme can be adapted to the specific practices of the unit.

The surgeon must accept the legal terms and conditions set by the BOA and sponsor on the homepage before entering the site. Once entered into the programme, the user may choose the relevant anatomical site and open the document for the particular operation. Two double-sided copies are printed, one for the patient and the other for retention in the clinical notes.

The choice of procedure, the technique to be employed by the surgeon and individual rates of complications are the key features of the site. All forms are kept as Microsoft Word documents (Microsoft Inc., Sacremento, California) which allows any surgeon to change the form to their individual specification and to permanently save those changes to their computer, memory stick or intranet site. These changes do not affect the master web copy.

The forms have been developed following legal and ethical advice ${ }^{5-7}$ and the guidelines of the Department of Health ${ }^{4}$ established in 2002 following the Bristol Royal Infirmary enquiry. These recommended a simple explanation of all procedures, complications, risks and rewards in layman's terms, aimed at patients with a reading age of 14 years, with advice concerning alternative procedures and the consequences of taking no action. The risks are graded: common, less common and rare.

Obtaining informed consent should be a continuous process. It is recommended that consent be undertaken initially when the patient is placed on the waiting list, again at the pre-assessment clinic and finally, on admission before the procedure. This allows 
the patient time to read the form and perform any other research before consenting.

There is also a space for the patient's signature which will allow data and discarded tissue to be used in a clinical trial, or for bone to be donated to a bone bank. The authors are also in discussion with the National Joint Registry to have consent for participation added.

These forms have been endorsed by the BOA, having passed through their Professional Practice Committee, the Medicolegal Committee and the Patient Liaison Group. There is no legal reason why they cannot be used in any hospital in the United Kingdom. However, it is suggested that they first pass through a Trust 'consent', or 'clinical negligence' committee, where consultant surgeons should have the opportunity to agree the wording. Changes can be made to suit the policy of a Trust.

The site is an evolving programme which will continue to improve. The more surgeons who use it and produce modifications, the better it will become. The website has a feedback section which allows users to contact the authors and suggest changes, additions and add new forms for additional procedures.

\section{Summary}

The website is not-for-profit and aims at enhancing the communication between doctor and patient by ensuring that patients are informed of all major and common complications and of alternative treatment where applicable.

The forms are quick and easy to print and leave more time for consultation with the patient. Individual forms follow Department of Health guidelines. Whilst we are under no illusion that the forms may not decrease the incidence of intended litigation, we feel confident that they will decrease the chances of its being successful. It is hoped that the legal profession will take note of what complications are detailed in the universal consent form and use it as a benchmark when the issue of informed consent is being discussed.

The authors acknowledge the donation by Finsbury Orthopaedics which covered the startup costs of the website.

\section{References}

1. Goodwin H. Litigation and surgical practice in the UK. Br J Surg 2000;87:977-9.

2. Sharma P, Arya A, Singh S. Informed consent for orthopaedic surgery: a prospective audit. Clincal Governance: An International Journal 2003;8:236-41.

3. Ibrahim T, Ong SM, Taylor GJ. The new consent form: is it any better? Ann $R$ Coll Surg Eng/ 2004;86:206-9.

4. No authors listed. The Department of Health. Reference guide to consent for examination or treatment. London: Department of Health, 2002. http://www.dh.gov.uk/ prod_consun_dh/groups/dh_digitalassets/@dh/@en/documents/digitalasset/ prod_consun_dh/groups/dh_digitalassets/@dh/@en/do
dh_4019079.pdf (date last accessed 2 January 2008).

5. Berg JW, Applebaum PS, Lidz CW, Parker LS. Informed consent: legal theory and clinical practice. Second ed. New York: Oxford University Press, 1987.

6. Faden RR. A history and theory of informed consent. New York: New York University Press, 1986:4-16.

7. Levine RJ. Ethics and regulation of clinical research. Second ed. New Haven: Yale University Press. 